\title{
Personal Residential Real Estate Investment in Australia: Investor Characteristics and Investment Parameters
}

\author{
Rayna Brown \\ Gregory Schwann ${ }^{*}$ \\ Callum Scott \\ Department of Finance \\ The University of Melbourne \\ Victoria 3010 \\ Australia \\ 9 August, 2006 \\ Revised: 13 December 2006
}

\begin{abstract}
To date out understanding of the factors affecting the housing supply stem from the private provision of new units through real estate development. This paper investigates a different aspect of housing supply, the private provision of rental housing through investment in existing properties. Using logistic regression and a series of micro datasets of Australian households we examine the investment decision of residential rental property investors over the period $1990-2004$. The sample period incorporates a full real estate cycle. Our results indicate that wealth-related factors are the dominant factors driving these investments. Life-cycle factors such as marriage and children play a less important role. Most of the determinants of income property investment do not vary with the property cycle. Marriage is an exception. It became more important as house prices rose.
\end{abstract}

Acknowledgements: For helpful comments we thank Rob Brown, Howard Chan, Les Colman, Qi Zeng and seminar participants at the AsRES/AREUEA Conference, Vancouver, 2006 and the Department of Finance, The University of Melbourne.

* Corresponding author

E-mail: $\quad$ g.schwann@unimelb.edu.au

Ph: $\quad 61-3-83443540$

Fax: $\quad 61-3-83446914$ 



\section{Introduction}

When considering the term 'housing supply', we generally envisage additions to, or deletions from, the physical stock of housing. Additions to the housing stock occur through the development of new housing units, or the maintenance, alteration and improvement of existing housing units. Deletions from the housing stock occur through the demolition of a unit or the permanent conversion of its use. ${ }^{1}$ Therefore, analysis of the aggregate supply of housing stock focuses on physical changes to housing units. Within this framework, it is also customary to consider the housing market as consisting of two sectors: the rental sector (non owner-occupied) and the owner-occupied sector. However, a change in the housing stock in one of these sectors does not necessarily involve physical change to the housing units; “cross-sector conversion” is a potentially important channel for changing the housing supply between the sectors. The physical unit does not have to be changed, only the use to which it is put.

In this paper we investigate the decision by private households to invest in residential (non owner-occupied) real estate. These private suppliers are important to the housing market in Australia and the US. In Australia, the private rental market provided housing for approximately 20\% of Australian households in 1995-96 (Australian Bureau of Statistics Cat. 8711.0). Most of the rental units are conventional two- and three-bedroom single-family homes. Individual/household investors are the primary suppliers of this rental housing, providing housing for approximately $60 \%$ of renter households (Australian Bureau of Statistics Cat. 8711.0, 1995). ${ }^{2}$ Shröder (2001) reports a similar situation in the US, where households supply approximately 75\% of rental housing. Thus, the investment decisions of individuals and households have a direct influence on the on the size and structure of the rental sector. There may also be an indirect effect on the owner-occupied sector, via the tenure choices of households, by influencing the relative benefit of owning versus renting.

There are surprisingly few studies that specifically examine residential income property investing by individual households. This study takes a step toward filling this gap. In this research, we examine three questions: (i) Who invests in income property? (ii) What financial and sociodemographic factors motivate income property investment? and (iii) How does income property investment change over the property cycle? The answers to the first two questions give us a description of the investor group and the factors which motivate them to invest in residential income property. The socio-demographics of the investor group are relevant because they link population demographics to the stock of rental housing. For example, the aging of the population in Australia and other Western economies may have resulted in an increase in the stock of rental housing. 
The third question is primarily about risk and return. We show that, as would be expected, the proportion of households investing in income property increases with the return on this investment, as it should. However, the coefficients of our explanatory variables do not change appreciably over the real estate cycle.

We use data from Consumer Income and Expenditure Surveys undertaken by the Australian Bureau of Statistics conducted in 1990-91, 1994-95, 1995-96, 1996-97, 1997-98, 1999-2000, $2000-$ 01, 2002-03 and 2003-04. The sample period covered by these surveys traces a full property cycle from recession in 1990, through the "property price bubble" in 2001 and into the "soft landing” of the housing sector in 2002-04. By using data from the full property cycle we are able to examine whether the factors that influence long-term investors differ from those that influence short-term investors.

The remainder of the paper is organized into six sections. In Section 2 we give a brief survey of the related literature. Section 3 describes the Australian context with respect to residential property investment. We include this section to assist non-Australian readers relate our results to the US or other markets. In Section 4, we outline our model, data and methodology. We also present a statistical description of residential income property investors in Australia. Our results and discussion are presented in Section 5. We conclude the paper in Section 6.

\section{Related literature}

It is possible to identify three broad streams within the real estate literature. The first stream encompasses studies which focus on real estate as an asset class within the life-cycle consumption model. The second stream focuses on the owner-occupier/tenant portfolio choice of households. The third stream is directed towards public policy and the provision of low-rent or public housing. Empirical evidence on the decision by private households to invest directly in residential income property is extremely limited and does not fit readily into a particular stream. Rather, it draws on aspects of all three. Therefore, we do not present comprehensive reviews of these three streams and instead we highlight the features of the literature that are relevant for our study.

Recent examples of studies that fall within the first stream are Arrondel and Lefebvre (2001), Flavin and Yamashita (2002), Flavin and Nakagawa (2003), Lustig and Van Nieuwerburgh (2005) and Fang (2005). These studies concentrate on the extent to which real estate investment (largely home ownership) fits with the hump-shaped path of wealth accumulation predicted by the lifecycle hypothesis. The macroeconomic issue is how real estate investment affects consumption smoothing. The summary evidence suggests that real estate investment makes the consumption 
pattern 'lumpy'. However, studies in this stream of the literature indicate that once the life-cycle theory is modified to include transaction costs, the possibility of joint consumption with other goods and the illiquidity of the investments, the observed pattern of real estate investment agrees with the pattern predicted by a revised life-cycle hypothesis. An implication is that real estate investment promotes consumption smoothing. The results reported in such studies indicate that standard life-cycle variables such as age and permanent income should appear in our model of income property investment.

Flavin and Yamashita (2002), Flavin and Nakagawa (2003), and Lustig and Van Nieuwerburgh (2005) examine real estate as an asset class within household portfolios. These studies focus on the importance of adjustment costs and household financial solvency in determining the composition of the optimal household portfolio. The basic idea is simple. A household does not have a free call on its future labor income when making consumption/saving decisions because it must maintain a non-negative financial position (financial solvency) or save to meet adjustment costs throughout its economic life. A household must alter its consumption/savings decisions relative to the decisions it would have made in an unconstrained environment. For example, if the household's financial position deteriorates, the household will decrease consumption and increase savings to meet its objectives. In turn, this implies that the market price of risk will rise and the household will reallocate its portfolio, placing greater weight on less risky assets. It is expected that the impact of solvency variables will become more important during poor economic conditions, such as the economic recession of the early 1990s and for more tightly constrained households.

The tenure choice stream in the literature draws on the consumption/life-cycle literature and portfolio theory to explain the choice between owner-occupation and rental accommodation by households. In the standard model, four factors determine tenure choice: the cost of owning relative to renting, borrowing constraints, permanent income and life-cycle factors. Early studies include Henderson and Ioannides (1983), Rosen (1985), Goodman (1988), Jones (1989), Linneman and Wachter (1989), Zorn (1989), Hendershott and Won, (1992) and Brueckner, 1997). ${ }^{3}$ Most of the tenure choice studies are cast in a partial equilibrium setting in which the supply of owneroccupied housing is assumed to be perfectly elastic and is not generally addressed. The supply side of the market is addressed in general equilibrium models, such as those discussed in Berkovec (1989), Meyer and Wieand (1996) and Crone and Voith (1999).

Empirical evidence suggests that investors in the United States may over-invest in real estate (Mills, 1987, Brueckner, 1997, Taylor, 1998). Such portfolio inefficiency is not necessarily at- 
tributable to irrational behavior on the part of homeowners. As outlined in Henderson and Ioannides (1983) the quantity of housing owned must be at least as large as the amount of housing consumed. The homeowner must balance the consumption benefits of the asset with the indivisibility of the housing investment. A higher marginal propensity to consume from housing as compared to financial assets provides further rationale for households to accumulate a higher concentration of assets in housing (Benjamin, Chinloy and Judd, 2004).

Despite the high weighting of owner-occupied housing in household portfolios, most of the literature on real estate as an asset class relates to the performance, pricing and management of diversified real estate investment trusts (REITs). ${ }^{4}$ As with other risky assets, the beta of the REIT security is important for assessing performance and for asset allocation decisions (Chiang, Lee and Wisen, 2005). Following studies such as McIntosh, Liang and Tompkins (1991) which reported that equity real estate investment trusts (EREIT) betas were declining, Chiang, Lee and Wisen undertook an analysis of the time-series properties of EREITs using both the single-factor model and the three-factor model of Fama and French (1993). Their results indicate that the betas estimated with the three-factor model are more stable than those estimated with the one-factor model and they conclude EREIT betas do exhibit long term stability.

In contrast, our study focuses on households that invest directly in residential income property rather than indirectly through listed property trusts. Meyer and Wieand (1996) show that in a competitive economy with well-diversified landlords, the returns from non-diversifiable housing investments will be priced according to a constant marginal price of risk. ${ }^{5}$ This result implies that the offer price for a house with riskier returns will be lower than the price of a similar house with less risky returns. Supportive evidence is reported by Gat (1994) for Tel Aviv and Crone and Voith (1999) for Montgomery County, Pennsylvania. ${ }^{6}$

The third stream of the literature relevant to our study examines the role of small income property investors in the provision of low-rent housing for people on low income. There are two core public policy issues that are addressed in this literature. The first is whether a more deregulated housing market will result in greater provision of low-rent housing. The second issue is whether these small investors should be supported by the public sector. Berry (2000) and Berry and Hall (2005) identify elements of public policy that are particularly relevant to the provision of low-rent cost public housing in Australia. An international perspective is given by Van Der Heijden and Boelhouwer (1996) who review and assess the private rental sectors of seven European countries. These studies conclude that the expected return from investing in residential income property is increasing. This improved outlook is associated with a swing in government policy away from 
public provision of rental housing to the private provision of rental housing. However, the authors argue that the expansion of investment in residential income property may not result in the provision of more low-cost housing. A similar point is discussed in Crook and Kemp (1996), who analyze the decline and partial revival of the private rental sector in the UK. They conclude that although deregulation of this sector was a necessary condition for revival of a healthy rental sector, deregulation cannot by itself ensure that a full range of rental accommodation is provided. This raises the question: should small income property investors be subsidized to provide low-rent housing?

Yates (1996) explores the role of private residential income property investors in the supply of low-rent housing in Australia. From analyzing survey data, Yates concludes that small investors (including unintentional investors, such as those temporarily renting out their main place of residence) are significant suppliers of low-income housing. In contrast, she argues that the shortterm mandates of fund managers make them unresponsive to the long-term returns generated from residential income property through capital appreciation. In her view, it may therefore be reasonable to encourage individual landlords rather than institutional ones. A favorable taxation regime for these small investors would reinforce their perception that their investment was longterm and secure.

Our review of the related literature indicates three important factors that should be incorporated in our empirical model. The first is that permanent income and life-cycles factors should be important determinants of private residential income property investment. The second, from the tenure choice literature, is that the ability to obtain mortgage finance may increase the probability of small investors entering the market. Some literature suggests that the total risk of investing in a residential property is priced in a competitive market. Therefore, at the margin, the total risk of a property is not a factor affecting residential property investment, except perhaps for uninformed investors. Finally, the low-rent housing literature highlights the roles of the property cycle (through population growth) and tax policy in promoting long-term investment in residential income property. We incorporate all of these factors in our model.

Before proceeding to a discussion of our model, we briefly describe the Australian context for investment in residential income property. In some respects it is quite different from many countries, including Canada and the United States, and therefore, in the interests of clarity, it merits a discussion. 


\section{The Australian context}

The Australian real estate milieu differs from those of many other countries. Not only has there been a high proportion of owner occupation - approximately 70\% - but also there has been a high level of investment in residential property by individuals and family units. This investment market has been particularly vibrant in recent years. Figure 1 depicts the share of mortgage commitments used to finance residential income property investment. Data from 1985 to 2005 is included to give a comprehensive picture of the investment trend. An increasing level of investment is evident over most of our sample period (1990-2004). The level of investment appears to plateau at approximately 30\% in the late 1990s 1990's but since that time has surged. In 2002 and 2003 approximately 38\%-40\% of new housing finance was for borrowers to acquire rental property.

In Figure 1, we also present the price series for established homes ${ }^{7}$ in Sydney. This series shows clearly the rapid growth over the 1990s. At the beginning of the decade, the average price for an established house was approximately $\$ 174,000$. At the end of the decade it was $\$ 310,000$, which represents a capital appreciation of approximately 6\% per annum. Prices have continued to rise since the millennium. They peaked in mid 2004 at \$520,000 which represents an appreciation of 13.9\% per annum since mid-2000. There was also significant price appreciation in Melbourne and Brisbane (the two other major east coast capital cities). In these cities, price appreciation was lower than the price appreciation in Sydney but followed the same general pattern over time. Hence, many investors in residential income property in the major cities of Australia earned high capital returns during our 1990-2004 sample period ${ }^{8}$.

\section{----- Figure 1 -----}

The levels of investment portrayed in Figure1 translate into a high percentage of households holding investment property in their asset portfolios. Using the 2002 Household, Income and Labour Dynamics (HILDA) Survey, Parlett and Rossiter (2004) show that more than 10\% of Australian households own investment property. As outlined by the Reserve Bank of Australia (Occasional Paper 16, 2003), in the United Kingdom less than $2 \%$ of households own residential investment property, whereas in Canada and the US approximately 6.5\% of households own rental property but this figure is falling. There, as in several other countries, institutions, charities and governments own a much larger proportion of such properties.

It is important to determine what encourages households to invest in residential income property (rental housing). ABS data from 1997 Rental Investors Survey yielded the following responses to 
that question with respect to property investors' most recent acquisition: long-term investment $66 \%$, attracted to negative gearing $15.7 \%$, rental income $15.1 \%$, future home $14.6 \%$, potential capital gain $8.8 \%$ and inability to sell $6.8 \%$. These percentages sum to more than $100 \%$ because multiple responses were allowed. The same data show that approximately $74 \%$ of these property investor owner properties single or semi detached houses, 22\% were single flats or units and 4\% were blocks of flats. Nearly half of all investment properties were located near the homes of investors (i.e., the same statistical sub-division). The overall picture is of property investors acquiring single houses close to their residence for long term investment, rather than opportunistic investment.

Australian institutional investors rarely own rental housing because the majority of properties in the rental market are self-standing properties on their own lots. For institutional investors this type of unit carries management inefficiencies without the prospect of exploiting economies of scale. In contrast, for institutional investors in countries such as Sweden and The Netherlands, are able to invest in inner-city blocks of apartments which do offer such economies. ${ }^{9}$

We therefore suggest that investment in residential rental property in Australia by household units is an important issue. It is important because of the absolute level of investment by households and because of the political/social ramifications. This is an under-researched area with the findings having important implications in Australia and elsewhere.

\section{Methodology and Data}

\section{Model specification}

Using logit regression, we estimate the probability of a household receiving income or incurring an operating loss from residential property. We include all types of residential income property. Since houses and units may have different risk and return characteristics, we would have preferred to segment the analysis or to include dummy variables to control for the type of property. Unfortunately, this is precluded because the dataset does not include a type of investment unit variable. We note that the analogous US dataset, the Consumer Expenditure Survey, also does not include a type of investment unit variable.

Our review of the relevant literature suggests that we include in our model variables which measure permanent income, life-cycle factors, the accessibility of mortgage finance and property cycle variables. While similar variables are used in models of home ownership and tenure choice, there is one important difference. When considering home ownership, one is investigating a joint consumption-investment decision but the purchase of residential rental income property is a pure in- 
vestment decision. Consequently, the factors influencing home ownership are an amalgam of investment factors pertinent to residential income property and the consumption factors pertinent to the choice of the amount, style and characteristics of the house the household desires. Household preferences, in particular, play a larger role in the choice of owner-occupied property. The factors that are expected to influence property ownership in general are well documented. ${ }^{10}$

We expect the decision to invest in residential income property to be affected by the lumpiness of residential property relative to other assets and by the banking rules governing the mortgage finance of income properties. Residential income property is similar to owner-occupied property in this regard. Mortgaging the property helps to alleviate the lumpiness problem but adds additional financial risk to the investment. We do not analyze the gearing decision in this paper. However, since most investors in residential income property are geared, we condition on gearing by including control variables.

Standard consumption-portfolio allocation models, such as Merton (1971), suggest that investment levels should be linear in household wealth. This prescription must be amended to include as initial range of zero investment for low-wealth households because the lumpiness of housing investment precludes small investments. Thus, we expect the probability of ownership to increase with wealth and, perhaps, to be sensitive to variables measuring household equity.

Our sample surveys do not include a wealth variable. Instead, we measure wealth with a set of proxy variables. We include a permanent income variable as a proxy for the value of a household's lifetime earnings. Permanent income is estimated using the methodology of Goodman and Kawai (1982) using data on the income level of the reference person in the household. Permanent income is determined by variables for age, gender, education, occupation and whether the individual is an immigrant. ${ }^{11}$ We also include transitory income in our investment model. We include transitory income because a positive income shock may enable an equity constrained household to enter this investment market. Transitory income is the difference between measured current income and permanent income. For comparability across time, both permanent and transitory incomes are measured in 2003-04 dollars. The all items consumer price index for each capital city is used to adjust nominal dollars to 2003-04 dollars.

We include two dummy variables for labor force participation: one for full-time employment of the reference person and the other for part-time employment of the reference person. The coefficients of these variables indicate the increase in the probability of ownership relative to an unemployed reference person. Higher labor force participation has two effects. First, it leads to higher incomes, but this effect is captured by our permanent and transitory income variable. Second, 
higher labor force participation implies greater income stability and less income-related risk in investment. This should increase the probability of investment.

The household may also utilize its existing equity in its home to underwrite the investment in residential income property. Thus, home owners should be more likely to make such an investment. We include a dummy variable for home-owning income units to capture this effect. In principle, we should exclude low-equity homeowners from this group, since they have no equity to access. We are not able to do this directly using the data in our surveys. Instead, we include a dummy variable for first-time homeowners, who are the most likely to be low equity households. We expect a first-time homeowner to be less likely to invest in residential income property.

A household's ability to invest in income property depends on its ability to raise the mortgage finance needed for the purchase. We include two variables: whether an income unit has one home mortgage and whether an income unit has two or more home mortgages. The reference category for these dummy variables is income units with no home mortgages. Both of the mortgage dummy variables indicate the household's ability to qualify for mortgage finance. Hence, the coefficients on both variables should have positive signs if they measure only access to mortgage finance. Unfortunately, the mortgage variables capture two other effects: a decrease in net wealth relative to a $100 \%$ equity investor and an increase in risk caused by gearing a property investment. Both of these other effects have a negative effect on income property investment. Consequently, the signs of these variables will depend on which effect is dominant.

Our mortgage variables are the only variables in this study that are influenced directly by the Australian institutional context. All mortgages in Australia are full recourse mortgages and most mortgages are extendable. This means that obtaining secondary finance to acquire an income property is a choice, not a requirement. Consequently, there is no simple equation between the number of mortgages and the financing of income property.

As life-cycle variables, we include variables measuring the age and marital status of the reference person and the number of children in the household. The age of the reference person is measured in years and is derived from a categorical age variable in the surveys by taking the mid-point of the range. Since age is our proxy for the household's position on the age-income profile, we expect it to exert a positive effect on the decision to invest in residential income property. Two dummy variables for marital status are included. The first is whether the reference person is married; the second is whether the reference person is divorced, separated or widowed. We expect the parameter on the married variable to be positive as married persons more readily purchase real estate because of the access to joint income. Conversely, we expect the parameter for di- 
vorced, separated or widowed to have a negative sign because of the separation of incomes. Prior financial commitments may reduce a household's ability to finance the purchase of income property. We argue that children are a core prior financial commitment and, therefore, the presence of children reduces the likelihood of investing in residential income property. We include three dummy variables for the number of children in an income unit: one child, two children and three or more children.

We have not included any variables for race. The dummy variables for Caucasian, African American, Hispanic and Asian present in US studies of tenure choice have no relevance in Australia. Our surveys include a country of birth variable that might be used to construct ethnicity dummy variables. However, these variables would not measure ethnic identity and values because they would not catch the descendents of immigrants to Australia. To a large extent, the country of birth variable separates immigrants from non-immigrants by date of immigration. We find that immigration is a consistent determinant of permanent income. However, when we included immigration in our logit regressions, the coefficients varied widely in sign and magnitude across the surveys. We conclude that the variables are too prone to sampling variability to be reliable and have dropped them from the analyses below.

Finally, the behaviour of first investors may differ from that of the seasoned investors because first investors know less about what they are undertaking. Unfortunately, the dataset does not include any variables that might be used as a proxy for first investors.

The logistic model to be estimated is:

$$
\begin{aligned}
I= & \beta_{0}+\beta_{1} \text { RINCC }+\beta_{2} D(\text { STATE })+\beta_{3} \text { PERMINC }+\beta_{4} \text { TRANINC }+\beta_{5} D(E M P)+\beta_{6} A G E+\beta_{7} M A L E \\
& +\beta_{8} D(\text { MSTATUS })+\beta_{9} D(C H I L D)+\beta_{10} O W N E R+\beta_{11} \text { FIRSTHO }+\beta_{12} D(M O R T)+\varepsilon
\end{aligned}
$$

where

I $=$ Logit index, where $\mathrm{I} \geq 0$ when the household has rental property income and $\mathrm{I}<0$ otherwise.

RINCC $=$ Rental property income

$D($ STATE $) \quad=$ Dummy variables for states of Australia which equal 1 when the household lives in VIC (Victoria), QLD (Queensland), SA (South Australia), WA (Western Australia), TAS (Tasmania), NTACT (Northern Territory and The Australian Capital Territory). The reference state is New South Wales (NSW). 


\footnotetext{
PERMINC = Permanent income estimated using the methodology of Goodman and Kawai (1982). Data is on the income level of the reference person in the household.

TRANINC $=$ Transitory income which is measured as the difference between measured current income and permanent income.

$D(E M P) \quad=$ Two dummy variables for labor force participation. FTEMP $=1$ when the reference person has full-time employment (0 otherwise). PTEMP = 1 when the reference person has part-time employment (0 otherwise).

AGE $\quad=$ The age of the income unit measured in years.

MALE $=$ Dummy variable $=1$ when the income unit is male.

$D$ (MSTATUS) Two dummy variables for marital status. MARRIED $=1$ when the reference person is married or in a de facto relationship ( 0 otherwise). DIVORCED $=1$ when the reference person is divorced, separated or widowed ( 0 otherwise).

$D(C H I L D) \quad=$ Three dummy variables for the number of children in an income unit: one child $($ CHILD1 $)=1$ when there is one child ( 0 otherwise), CHILD2 $=1$ when there are two children ( 0 otherwise) and CHILD3 $=1$ when there are three or more children (0 otherwise).

OWNER Dummy variable $=1$ when the income unit owns their own home mortgage $(0$ otherwise).

FIRSTHO Dummy variable $=1$ when the income unit is a first home buyer mortgage $(0$ otherwise).

$D(M O R T) \quad$ Two dummy variables for the number of home mortgages held by the income unit. NMORT1 $=1$ when the income unit has one home mortgage $(0$ otherwise). $N M O R T 2=1$ when the income unit has two or more home mortgage ( 0 otherwise).
}

\section{Data}

Data were obtained from the following confidentialized unit record files (CURFs) from the Survey of Income and Housing (SIH) conducted by the Australian Bureau of Statistics (ABS). ${ }^{12}$ Nine surveys are included, covering the time periods 1990-91,1994-95, 1995-96, 1996-97,1998-99, 1999-00, 2000-01, 2002-03 and 2003-04.

The SIH is conducted throughout Australia. The data collected pertains to sources (and amounts) of income received, housing details and other demographic and labor force information. The sample for SIH is a sub-sample of the private dwellings included in the ABS Monthly Population 
Survey. Information was collected by interview from the residents of private dwellings in both urban and rural Australia. Private dwellings are defined as households, apartments, home units, caravans, garages, tents and other structures used as places of residence. Not included are hotels, boarding houses, boarding schools, institutions, households of defense force personnel, households of personnel from overseas governments and remote households of the Northern Territory.

The dimensions of the sample and population are outlined in Table 1. The number of income units in the survey is listed in the second column. On average, approximately 10,000 income units are polled each survey. The number of income units in the population is shown in column five. This column is calculated by weighting each income unit by the number of population units it represents in the survey. The figures in column five show that the number of income units rose monotonically from 1990-91 to 2003-04 at an average rate of 3.5\% per annum. The number of income units holding residential income property (column 6) also grew but the growth rate, at $6.8 \%$ per annum, far exceeds the growth rate in the number of income units. These rates indicate that there has been a shift toward investing in residential income property over the years 19902004. This shift is reflected in a rise in the percent of income property owners in the sample (column 3) and in the population (column 7).

----- Table 1 -----

The trend towards investment in residential income property is illustrated in Figure 2. Income property investment increased steadily over the 1990s, despite the economic recession that occurred between the 1990-91 and 1994-95 surveys. The growth in investment plateaued in 1999, with $7.5 \%$ of income units holding income property. Since 1999, the level has fluctuated slightly around $7.5 \%$ of income units holding income property. The broad question that arises from our examination of Table 1 and Figure 2 is what caused this shift toward income property investment? Figure 2 indicates that the trend in income property investment followed the rate of house price appreciation. Where investors simply chasing capital gains? We believe that this conclusion would be premature. Changes in the investment fundamental can also explain the trend toward income property investment. The sample period was one of strong economic growth and low interest rates and these fundamental factors may have fueled the increases in both property investment and property prices. Our econometric analysis in the next section examines the determinants if income property investment in detail. 
In Table 2, we present the panel means of the variables used in this study. ${ }^{13}$ We use a two-step weighting procedure in calculating these means. The first step is to weight each observation in a survey by its probability of inclusion in the sample using the weights provided in the survey dataset. The second step is to scale the data in each survey so that the sum of the weights equals the average sample size. This scaling is needed because the surveys are of unequal size. As a result of our scaling, each survey contributes equally to our statistical results.

In the first two columns of Table 2, we give the acronyms of the variables used in our analysis. In the third and fourth columns, we present the means of the variables for all the observations in the panel of samples and the means for all the income property investors in the panel of samples, respectively. We record the difference between these means in column five and the $t$-statistics for the null hypothesis of no difference in column six.

Referring to the data in Table 2, it is apparent that investors in residential housing are statistically different from the general population in all dimensions (with the exception of those investors resident in NSW). Income property investors have higher permanent incomes than the general population by $\$ 260$ per week on average, which corresponds to an annual permanent income difference of over $\$ 13,520$. Income property investors also have higher transitory incomes. This indicates that they are earning above their age-education-occupation peers. The average difference is $\$ 196$ per week or $\$ 10,192$ per year. In total, they earn $\$ 456$ per week or $\$ 23,712$ per year more than the general population.

----- Table 2 -----

The higher incomes of income property investors are substantiated by the differences in the other income related variables. They are 17.6 percentage points more likely to be employed full time and 1.6 percentage points less likely to be employed part time; they are 14.7 percentage points more likely to be male; they are 25.2 percentage points more likely to be married and 5.5 percentage points less likely to be divorced, widowed or separated. Income property investors also are slightly older - three years older on average.

Some of the additional income earned by income property investors is spent on things other than income property. These income units are less likely to be childless. ${ }^{14}$ This is indicated by the increases in the percentages of income units having one, two or three or more children. The increase is most pronounced for two children income units. Income property investors are substantially more likely to be home owners. On average, they are $23.3 \%$ more likely to be home owners. They are also $1.6 \%$ less likely to be first homeowners. The percentage of homeowners rose 
slightly with the real estate cycle but this percentage has fallen off in the 2000s as the rate of capital appreciation has declined.

----- Figure 3 -----

Income property investors did not shoulder homeownership, the investment in income property and child care expenses on their current incomes alone. They also incur more debt. They are 5.3 percentage points more likely to have one mortgage and 2.6 percentage points more likely to have two or more mortgages. Figure 3 indicates that the difference in the incidence of mortgage debt is particularly strong in the late 1990s surveys, at the peak of the property price cycle. The difference of means for mortgage debt shows a clear change over the real estate cycle. With the exception of the 2003-04 survey, the difference in the percentage of second mortgage holders also shows a clear change over the cycle. Anecdotal evidence suggests that a change in bank lending practices may have caused the increase in percentage of second mortgages held by income property investors. Specifically, banks removed a cap on the number of investment properties on which they would make loans for each investor and more aggressively marketed interest only loans as the preferred income property loan. The latter change required taking a second loan rather than extending a single primary loan.

The changes in the means of percentage of mortgage income units suggest that the Australian banking sector enabled the increase in income property investment by extending the loans of already mortgaged income units and by making second mortgages easier. This makes sense for the lenders because the high rates of house price appreciation make mortgage default unlikely. However, it is not clear that the ease of mortgage finance plays a role in spurring income property investment. Mortgage finance must have been constrained initially and the constraint loosened over the real estate cycle for mortgage finance to accelerate investment. If this is the case, the coefficients on our mortgage variables must be negative in 1990-91 and decrease in magnitude through the mid to late 1990s. The estimated coefficients (see Table 5 and Figure 5 below) conform roughly to this pattern. Thus, easier mortgage finance explains a portion of the increase in income property investment.

Regional differences are apparent in the level of income property investment by households. There is a higher incidence of income property investment in Queensland (2.4\%), Western Australia (1.0\%) and the Northern and Australian Capital Territories (1.2\%), and a lower incidence in New South Wales (-0.3\%), Victoria (-1.8\%), South Australia (-2.0\%) and Tasmania (-0.5\%). However, these average figures do not tell the whole story because they do not take into account 
regional investment trends. The trends for New South Wales (Sydney), Victoria (Melbourne) and Queensland (Brisbane) are illustrated in Figure 4. The trends for the other states are less pronounced and have been omitted for graphical clarity. In New South Wales, the incidence of income property ownership follows a counter-cyclical pattern, being lower in the early surveys when house price appreciation was strongest and higher in the later surveys when house appreciation slackened. This pattern is reversed in Victoria and Queensland. The incidence of income property investment was higher at the bottom of the real estate cycle than at the top of the cycle. The incidence of income property investment in Tasmania follows that in Victoria. The odd spike in the 1995-96 percentage of income property investors in Queensland reflects the Gold Coast property boom that occurred at that time. While it is easy to spot the patterns in the incidence of income property investment across the real estate cycle, it is not clear what drives these investment patterns, particularly those in New South Wales, Victoria and Tasmania.

\section{----- Figure 4 -----}

Our comparison of residential income property investors and non-income property investors, answers our first research question: Who invests in residential property? We find that residential income property investors are significantly wealthier, as expected. We also find that earn above their age-education-occupation peers; that is, they appear to be high achievers. This was not expected. In part, these results reflect the higher probability that residential income property investors are full time workers. Further, we find that these investors have accumulated more assets as indicated by their higher probability of being homeowners and lower probability of being first time home owners. We expect all of these results to carry over to other countries since there is nothing country-specific in their determination. Two further results may be specific to Australia. We find that residential income property investors are predominantly male. This may be an artifact of the survey instrument. Second, we find residential income property investors are likely to carry a mortgage. This may or may not be peculiar to the Australia lending environment.

We find it reassuring that residential income property investors are different both statistically and in meaningful economic dimensions. In the next section, we investigate how these differences translate into property investment.

\section{Results}

We present our main results in two tables. In Table 3 the panel estimates for the sample period 1990-2004 are reported. In Table 4 the results for regressions estimated on cross-sectional data are reported. The sample period 1990-2004 includes nine surveys. As previously discussed this 
sample period incorporates data from across the full property business cycle in Australia. The property market collapsed in 1990 with the start of the recession. Prices slowing increased until 1994-95 when the trend reversed and prices began to rise more rapidly. The prices grew rapidly until 2002-03, when they peaked in most of the capital cities. Since then prices have fallen in most markets. ${ }^{15}$

\section{Panel estimates}

The purpose of the panel estimates in Table 3 is to evaluate the long-run impacts of the independent variables across the property cycle. The coefficients are estimated by weighted logit. The weights used in the estimation are the same weights used to calculate our panel means in Table 2. Hence, each survey has equal weight in determining the estimates. We present the estimates from two models in Table 3. Model 1 includes all the variables we have selected as investment determinants. The estimates show that the likelihood of owning income property increases with increased age and increased wealth. Being married rather than single and being a homeowner are also significant factors increasing the likelihood of owning rental property. Factors which lower the likelihood include having a larger number of dependant children and being male. There are marked differences between states. Residing in Tasmania, South Australia or Victoria reduces the likelihood of owning rental property, while residing in Queensland, Western Australia or the Territories increases the likelihood.

The fourth column in Table 3 shows the impact of the difference in means between residential income property investors and the general population (see Table 2) on income property investment. It is calculated as the coefficient multiplied by the difference of means. The calculations show that only the permanent and transitory income effects and home ownership have a financially relevant impact, and it is permanent income that dominates the result.

----- Table 3 -----

We have one peculiar result. The effect of full-time participation in the labor force has a statistically significant negative effect on the probability of holding an income property investment. When we couple the negative coefficient with the higher rate of full-time employment for income property investors (see Table 2) we get a large difference effect. This indicates that full-time employment is a significant deterrent to income property investment.

Several reviewers of this paper have suggested that the negative sign on labor force participation occurs because full time employment limits the time available to work on the management and maintenance of income properties. Small time investors who are employed full time would find it 
necessary to hire a manager and/or repair people to manage and maintain their income properties or to devote their leisure hours to these activities. Because of these extra costs, the return to income property is lower for full time workers and this reduces their incentive to invest.

This argument is appealing because it is based on the "real world" objectives and constraints faced by small time income property investors. Unfortunately, it does not agree with the facts. According to the argument, we would expect, at the margin, to see fewer full time employed and more part time employed in the sample of residential property investors than in the general population. In Table 2, we show that full time works are $17.6 \%$ more likely to be income property investors and part time workers are $1.6 \%$ less likely to be income property investors. We doubt that the controls in the logit equation can explain such large differences in the percentages. However, a full examination would require a study of technology of personal investment and the role of work time substitution in this technology.

Another plausible explanation is that the negative effect of full time employment is spurious and the variable is really capturing the effect of a shift in the composition of the labor force. The effect on the labor force of increasing the proportion of workers in full-time employment, holding part-time employment constant, is to draw workers from the pool of unemployed and non-labor force participants directly into full-time employment. This includes households across the full social spectrum, from the unemployed to independently wealthy self-funded retirees. If these added workers have a lower propensity to invest in residential income property, then the strong economy in the mid 1990s should be accompanied by a negative coefficient on the variable FTEMP, as observed.

Our results for gender are also interesting. If the respondent is male, the likelihood of being an income property investor decreases. There are two potential explanations for this result. First, the coefficient may reflect a risk preference of female investors relative to comparable male investors. We are unable to test this hypothesis using our data. Another potential explanation for this result is the longer life expectancy of women. All things being equal, older women are more likely to hold income property than older men. This explanation is consistent with the positive effect of age. We attempted to test this hypothesis by including in our logit equations a retirement dummy variable (Retired=Age $\geq 65$ ) and a dummy variable for retired, widowed females, calculated by multiplying Retired $\times$ Divorced, Separated, Widowed $\times$ (1-Male). Both these new variables were statistically insignificant and, while the coefficient on the $M A L E$ variable increased slightly, it remained negative and statistically significant. Our failure to find a retired female effect may be due to the poor quality of our Retired dummy variable - Australians may 
retire any time after age 55 - and our inability to distinguish widowed females from divorced and separated females.

Model 2 extends Model 1 by adding a fixed effects dummy variable for each survey. The dummy variables are proxies for the state of the property investment market at the time of the survey relative to the state of the market in 1990-91 (our reference period). As noted previously, in 1990-91 the property investment market was in recession. Because of this choice for the reference period, all of the fixed effect variables are positive, indicating that the property investment market was consistently better following the recession. The estimated coefficients describe an inverted U shape with a broad peak between 1995 and 1997. This was a time period of sustained high capital returns to investment in residential income property. The coefficient for the 2003-04 survey is statistically insignificant and, therefore warrants discussion. This indicates that the investment sentiment during this year was roughly comparable to the sentiment in the early 1990s. No recession followed 2004 and it will be interesting to re-estimate this model when the 2004-05 data becomes available to examine whether the investment sentiment improved.

The introduction of the state-of-market dummy variables does not alter the conclusions we reached on the basis of Model 1but there are several noteworthy changes in the coefficients. The largest change is in the coefficient for full-time employment (FTEMP) which decreases from 0.172 to -0.606 . This result indicates that full-time employment may actually curtail income property investment to a larger degree than was apparent from Model 1. The implication is that full-time employment works through two channels. Full-time employment directly reduces residential property investment but macroeconomic growth stimulates residential property investment by increasing the security of employment. The impact of second mortgages also changes considerably once the controls for the state of the market are introduced in Model 2. The coefficient on MORT2 increases from -0.145 to -0.009 and becomes statistically insignificant. It appears that economic growth reduces the risk of holding mortgage debt and this induces greater residential property investment.

While our panel estimates show that most of the variables are statistically significant, the difference effect shows that few of the variables are financially significant. What emerges is a simple investment story. The core long run determinant of income property investment is wealth, as measured by permanent income and home ownership. In comparison, tenure choice studies show an array of life-cycle factors have a significant impact on the probability of homeownership. We view this as a general result that is not tied to the Australian context. We find that transitory income increases the probability of making an investment in residential property. This result may 
be tied to the strong economic performance of Australia during our sample period. Alternately, our transitory income variable may reflect high earnings achievement by income property investors, rather than abnormal economic circumstances. If this is the case, transitory income should increase residential income property investment in other countries. Full time workers are significantly less likely to invest in residential income property. If our explanation for this result is correct, the result is driven by the characteristics of the dataset and will not generalize. Finally, while the fixed effects for each survey are individually and jointly statistically significant, the difference effects indicate that they have little impact on the probability of investing in residential income property. This result indicates that the real estate cycle did not have a long run effect on investment and it suggests that investors view residential income property as a long term investment. As previously noted, 66\% of the investors surveyed in the 1997 Rental Investors Survey stated that their acquisitions were for long term investment.

\section{Survey-by-survey estimates}

To estimate the panel models, we constrained the coefficients to be constant across the fourteen years spanned by the nine surveys. This allowed us to interpret the estimates as long-run effects. However, the estimates for the individual surveys may depart from our long-run estimates because the independent variables may affect the decision to invest in residential income property in a different way at different points in the property cycle. There is also considerable scope for sampling variability because income property investors constitute only $6.5 \%$ to $7.5 \%$ of the sample. We examine this conjecture using a series of nine tests for homogeneity of the parameter estimates. In each test the null hypothesis is that the parameter estimates are constant. The alternate hypothesis is that the parameter estimates are constant for all of the surveys except one. These hypotheses are tested using a likelihood ratio test. The prob. values shown in the fourth column reject the null at the 5\% significance level for every survey except 1997-98. In the final row of the table, we present the test of the null of parameter homogeneity against the alternative that all the surveys have distinctive parameters. The null is soundly rejected. From these tests, we conclude that short run, survey-by-survey results need to be investigated. We devote the remainder of this section to this investigation.

\section{----- Table 4 ------}

We present our estimation results for each survey year in Table 5. To assist interpretation of these results, they are also presented graphically in Figure 5. In principle, one should exercise more caution in reviewing these results than in reviewing our panel results because they are more 
closely tied to economic circumstances prevailing in Australia at the time of each survey. The results may not generalize to other countries as easily. Nevertheless, we are reassured by the fact that, in broad qualitative terms, the results of these estimations are similar to those already discussed for the panel estimates. The parameters vary in magnitude and statistical significance from survey to survey but the picture stays the same. Consequently, our discussion focuses on differences across time.

First, we examine the wealth-related variables. Permanent income is the most important determinant of residential income in all the regressions. Moreover, there is no discernable time pattern in the coefficients for permanent income. In contrast, the coefficient for transitory income declined from 0.089 per $\$ 100$ in $1990-01$ to 0.043 per $\$ 100$ in 2003-04 (Figure 3, Panel A). At the same time, the average transitory incomes of residential income property investors declined. This trend is reflected in a decline of the difference effect from 0.309 in 1990-01 to 0.067 in 2003-04. Thus, the relative importance of permanent income compared to transitory income has risen over the sample period. This finding does not mean that transitory income is unimportant; indeed, transitory income is statistically significant in every regression, suggesting that income property investment increases when income units receive positive shocks to income. However, the level of the shock required for this effect to occur has increased over the sample period.

The coefficients of the labor force participation variables are illustrated in Panel B of Figure 5. Our panel estimates (see Table 3) show that full-time labor force participation decreases the likelihood of investment in residential income property. This negative effect is also apparent in Table 5, which shows that the coefficient is significantly negative in every survey except 2002-03. The magnitudes of the coefficients vary considerably across the surveys, from a low of -1.037 in 1994-95 to a high of -0.378 in 2002-03. We can not offer explanation for this variation.

In our panel regressions, the sign of the variable PTEMP differed between Model 1 and Model 2 (see Table 3), which suggests that the effect of part time employment on property investment varied over the property cycle. We are unable to confirm this inference with the cross-sectional regressions reported in Table 5. The PTEMP variable displays an erratic pattern of signs across the survey years. It is statistically insignificant in all regressions and the variable has very little economic effect on income property investing, as indicated by the impact of the difference effect.

The patterns for the coefficients on AGE, the Marital Status Variables (MARRIED and DIVORCED) and gender (MALE) are surprising (Figure 5, Panels C, D). First, except for the 199091 survey, the coefficients on AGE are statistically insignificant, which suggests that age, by itself, is largely irrelevant to the investment decision. This conclusion appears at odds with the 
significantly positive coefficients on $A G E$ in the panel regressions. We suggest that this difference arises because the age effect is channeled through permanent income in the regressions reported in Table 5, while the extra time depth of the panel regression allows age to emerge as an independent factor. If we are correct, the $A G E$ effect in the panel regressions may be a cohort effect in disguise.

The estimated coefficients of the variable MARRIED decline in magnitude through the early 1990s and are statistically insignificant over of the early to mid 1990s. However, this pattern changes in the late 1990s as the estimated coefficients increase in magnitude and become statistically significant from the 1997-98 survey. Figure 5D outlines the changes in these coefficients. These changes in the coefficients on MARRIED parallel the time path of house price appreciation in Australian cities, indicating that a second income has become more important as house prices have risen relative to income. This result also suggests that the income returns to residential property investment do not fully support the investment and that a second income is needed to obtain mortgage finance, or to meet the running costs of the investment or to provide insurance against mortgage default. Presumably, income units place themselves in this position in order to capture a capital return. This view is supported by the reduction in the coefficient on MARRIED for the 2002-03 and 2003-04 surveys, when capital returns had largely disappeared. However, the coefficient remains positive and significant in these surveys. One possible explanation is that a substantial number of residential income property investors have held on to their properties, perhaps viewing the decline in capital return as temporary. The effect of marital dissolution is similar to that of marriage but in the opposite direction. It appears that marital dissolution leads to a greater sell-off of residential income property when the property market is weakest. In effect, the income units in Australian cities are good portfolio re-balancers.

The coefficient on the variable MALE is strongly negative in all but one survey but the coefficients are statistically insignificant in all years except 1997-98 and 2003-04 (Figure 3, Panel C). We do not have a plausible explanation for the sign of this variable. The fact that the magnitude of the coefficient varies considerably across the surveys and that it becomes statistically insignificant in the survey regressions suggests that the variable may be capturing a facet of the sample selection and data collection procedures used by the Australian Bureau of Statistics for this survey.

In the panel regressions, we found that the more children there are in the household, the lower the likelihood that an investment property is held. This agrees with our hypothesis that having children absorbs potential investment funds; one might regard children as a competing investment. 
The survey level regressions in Table 5 do not support this hypothesis. The CHILD variables are consistently statistically insignificant. Our interpretation of these conflicting results is that children are a long-run investment and that the fourteen-year panel regression is picking up the longrun impact of having children. The short-run survey-by-survey regressions cannot separate this long-run effect from the demographic noise in the background. We require longitudinal data to test the validity of this interpretation.

Across the surveys, homeownership (OWNER) has a positive effect on residential income property investing and first homeownership (FIRSTHO) has a negative effect (Figure 5, Panel F). The coefficients on the variable for homeownership (OWNER) confirm the standard life-cycle hypothesis that increases in household wealth lead to greater asset holdings across all investment types. The variable for first homeownership (FIRSTHO) was included to control for low-equity home-owners. Thus, the negative coefficient on this variable also confirms theoretical expectations. Theory also suggests that solvency-constrained households have a higher marginal price of risk and therefore are less likely to engage in risky investments. Since the mortgagee obligations of many first home owners make them financially constrained, the lower propensity of first homeowners to invest in income property may reflect a lower tolerance for risk.

In our regressions, first homeowners are both homeowners and first homeowners. Therefore, the impact of first homeownership is the sum of the coefficients on the two homeownership variables. This sum (net effect) is given as the third bar in Figure 5, Panel F. From the figure, there does not appear to be a relationship between the net first homeownership effect and the property cycle. The net effect varies between positive and negative period during both the upturn in the market between 1994 and 1996 and the downturn in the market in 2002-04, suggesting that the net effects are statistical artifacts.

----- Table 5 -----

----- Figure 5 -----

The parameters which change sign include age, marital status and number of mortgages. Figures The last variables are the two mortgage variables, NMORT1 and NMORT2. We expect debt on one's principal residence to deter investment in income property because it reduces net wealth. We observe this effect in the coefficients on NMORT1, which are consistently negative and statistically significant across the sample period. However, the effect appears to declining over time as the average magnitude of the coefficients is larger in the first four surveys than in the last five 
surveys. This may be the result of less stringent loan underwriting criteria being applied in the late 1990s. Anecdotal evidence indicates that lenders were very willing to lend for income property investment during the property boom of the 1990s and continued this practice into the early 2000s. Unfortunately, we have no direct evidence for this claim other than the increases in bad debts for major lenders since this period. The coefficients on NMORT2 are of mixed sign and statistically insignificant for the 1999-00, 2000-01 and 2001-02 surveys. This result is surprising given the long-term growth in second mortgages portrayed in Figure 3. However, in every survey the number of residential property investors holding second mortgages is small and we suspect that the variability of the results may be due to pure sample variability. Our view is supported by the results in the panel regression. The aggregation of second mortgage holders allows greater averaging of income unit idiosyncrasies and we find that NMORT2 has a consistent negative sign, as expected.

In summary, our survey-by-survey estimates yield two results that may be applied more generally. First, during a period of economic growth, transitory income falls in importance relative to permanent income as a determinant of residential income property investment. The reason for this is that economic expansion leads to permanent income growth and, as a result, permanent income overtakes and dominates the transitory component of income. Second, during a period of rapid house price appreciation, being married increases the probability of investment because a second income makes it easier to obtain mortgage finance, to meet the running costs of the investment, or to self-insure against mortgage default. Our estimates also yield one result tied to the Australian market. We find that more liberal mortgage lending tends to reduce the negative effect of existing debt on residential income investment. However, the difference effects tabulated in Table 5 show that the impact of the changes in lending is small.

\section{Conclusion}

Our research pursued answers to three questions: (i) Who invests in residential property?; (ii) What financial and socio-demographic factors motivate income property investment? and (iii) How does income property investment change over the property cycle? In answer to the first question, we reported in section 4, that households investing in residential income property are wealthier, who are employed full-time and who earn more than their peers in terms of their age, education and occupation. They tend to be male-headed, married with large families. Also, they are more likely to be mortgaged, either for their principal residence or for the income property itself. 
We investigated the second question in section 5. We found that an income unit's wealth is the dominant socio-demographic factor motivating income property investment. Wealth is captured by the variables for permanent income, transitory income and full-time employment (albeit negatively). Marriage is the only demographic factor of importance, although one might argue that this is an indicator of income stability. Lastly, for obvious reasons, the ability to get a mortgage is important to investing in income property.

We find the answer to our last research question surprising. Only one of the investment determinants - marital status -- showed true cyclic variation. Being married tends to be most important when house prices are high relative to income. The plausible reasons for this result are that the second income is needed either to obtain mortgage finance or to meet the running costs of the investment or to provide insurance against mortgage default. Only transitory income displays a secular trend. Our results suggest that transitory income declined in importance over the sample period. This finding may be a reflection of the strong economic growth in Australia over most of our sample period. With stable income, residential income property investors are drawn from the wider population, not just the lucky few who are doing abnormally well in their occupations.

Finally, this research examines the determinants of holding residential income property. It does not examine the determinants of entry to and exit from this investment market. Therefore, we regard the research as somewhat incomplete. This deficiency cannot be addressed using our primary survey data as we are unable to accurately identify those entering and leaving the market. We will address entry and exit in our future research. 


\section{References}

Ambrose, B.W. and P. Linneman (2001), REIT Organizational Structure and Operating Characteristics, Journal of Real Estate Research, 21 (3), 141-163.

Arrondel L. and B. Lefebvre, (2001), Behavior of Household Portfolios in France: The Role of Housing, Review of Income and Wealth, Series 47 (4), 489-514.

Benjamin, J. D., de la Torre, C. and J. Musumeci, (1998), Rationales for Real Estate Leasing versus Owning, The Journal of Real Estate Research,15 (3), 223-237.

Benjamin, J.D., Chinloy P. and G.D. Judd, (2004), Why do Households Concentrate their Wealth in Housing, The Journal of Real Estate Research, 26 (4), 329-343.

Berkovec, J. (1989), A General Equilibrium Model of Housing Consumption and Investment, Journal of Real Estate Finance and Economics, 2, 157-172.

Berry M., (2000), Investment in rental housing in Australia: small landlords and institutional investors, Housing Studies, 15 (5), 661-681.

Berry M. and J. Hall, (2005), Institutional investment in Rental Housing in Australia: A Policy Framework and Two models, Urban Studies, 42 (1), 91-111.

Brueckner, J. K., (1997), Consumption and Investment Motives and the Portfolio Choices of Homeowners, Journal of Real Estate Finance and Economics, 15 (2), 159180.

Chiang, K. C. H., Lee M-L and C. H. Wisen (2005), On the Time Series Properties of Real Estate Investment Trust Betas, Real Estate Economics, 33 (2), 381-396.

Crook A. D. H. and P. A. Kemp, (1996), The Revival of Private Rented Housing in Britain, Housing Studies, 11 (1), 51-68

Crone, T.M. and R.P. Voith (1999), Risk and Return within the Single Family Housing Market, Real Estate Economics, 27(1), 63-78.

DiPasquale, D. (1999), Why Don't We Know More About Housing Supply?, Journal Real Estate Finance and Economics, 18(1), 9-23.

Fama, E. and J. MacBeth (1963), Risk, Return, and Equilibrium: Empirical Tests, Journal of Political Economy, 71, 607-636.

Fang Yang, (2005), Consumption Along the Life Cycle: How Different Is Housing? Research Department, Federal Reserve Bank of Minneapolis, Working Paper 635.

Flavin M. and T. Yamashita, (2002), Owner occupied housing and the composition of the household portfolio, The American Economic Review, 92 (1), 345-362.

Flavin, M. and S. Nakagawa (2003), A model of housing in the presence of adjustment costs: A structural interpretation of habit persistence, NBER Working Paper 10458.

Gat, D. (1994), Risk and Return in Residential Spatial Markets: An Empiric and Theoretic Model, Journal of Real Estate Finance and Economics, 9(1), 51-68.

Goodman, A.C. (1988), An econometric model of housing price, permanent income, tenure choice and housing demand, Journal of Urban Economics, 23, 327-353.

Goodman A. C. and M. Kawai, (1982), Permanent Income, Hedonic Prices, and Demand for Housing: New Evidence, Journal of Urban Economics, (12), 214 - 237. 
Henderson, J. V. and Y. M. Ioannides, (1983), A model of housing tenure choice, The American Economic Review, 73 (1), 98-113.

Hendershott, P. H. and Y. Won, (1992), Introducing Risky Housing and Endogenous Tenure choice into a Portfolio-Based General Equilibrium Model, Journal of Public Economics, 48, 293-316.

Jones, L. (1989), Current Wealth and Tenure Choice, Journal of the American Real Estate and Urban Economics Association, 17(1), 7-40.

Kohler, M. and K. Smith, (2005), Housing and the Household Wealth Portfolio: The Role of Location, Research Discussion Paper 20005-10, Economic Research Department, Reserve bank of Australia.

Linneman, P. and S. Wachter (1989), The Impact of Borrowing Constraints on Homeownership, Journal of the American Real Estate and Urban Economics Association, 17(4), 389-402.

Lustig, H. and S. Van Nieuwerburgh (2005). Housing Collateral, Consumption Insurance and Risk Premia: An Empirical Perspective, Journal of Finance, 60 (3), 11671219.

McIntosh, W. Liang Y and D.L. Tompkins (1991) An Examination of the Small-Firm Effect within the REIT Industry, Journal of Real Estate Research, 6 (1), 9-18.

Merton, R. C. (1971), Optimum Consumption and Portfolio Rules in a Continuous Time Model, Journal of Economic Theory, 3, 373-413.

Meyer, R. and K. Wieand (1996), Risk and Return to Housing, Tenure Choice and the Value of Housing in an Asset Pricing Context, Real Estate Economics, 24, 113131.

Parlett N. and A. Rossiter, (2004), Residential Property Investors in Australia, Reserve Bank of Australia Bulletin, May, 52-56.

Rosen, H. (1985), Housing Subsidies: Effects on Decisions, Efficiency, and Equity. In A.J. Auerbach and M.S. Feldstein, editors, Handbook of Public Economics, 1, North-Holland: 375-420.

Shröder M., (2001), What Makes a Landlord? Ownership of Real Estate by US Households, Urban Studies, 38 (7), 1069-1077.

Taylor, L. L., (1998), Does the United States Still Overinvest in Housing?, Economic Review, Federal Reserve Bank of Dallas, $2^{\text {nd }}$ quarter, 10-18.

Van Der Heijden H. and P. Boelhouwer, (1996), The Private Rental Sector in Western Europe: Developments since the Second World War and Prospects for the Future, Housing Studies, 11 (1), 13-34.

Yates J., (1996), Towards a Reassessment of the Private Rental Market, Housing Studies, 11 (1), 35-50.

Zorn, P. (1989), Mobility-Tenure Decisions and Financial Credit: Do Mortgage Qualification Requirements Constrain Homeownership? Journal of the American Real Estate and Urban Economics Association, 17(4), 1-16. 
Table 1

The Dimensions of the Sample and Population

\begin{tabular}{crrrrrr}
\hline & \multicolumn{3}{c}{ Sample } & \multicolumn{3}{c}{ Population } \\
\cline { 2 - 7 } & $\begin{array}{r}\text { Income } \\
\text { Yncome } \\
\text { Yroperty }\end{array}$ & $\begin{array}{r}\text { \% Income } \\
\text { Property } \\
\text { Ownits }\end{array}$ & $\begin{array}{r}\text { Income } \\
\text { Owners }\end{array}$ & $\begin{array}{r}\text { Income } \\
\text { Property } \\
\text { Owners }\end{array}$ & $\begin{array}{r}\text { \% Income } \\
\text { Property } \\
\text { Owners }\end{array}$ \\
\hline \hline $1990-91$ & 18,294 & 1,023 & $5.59 \%$ & $7,988,663$ & 444,160 & $5.56 \%$ \\
$1994-95$ & 8,549 & 571 & $6.68 \%$ & $8,501,109$ & 533,964 & $6.28 \%$ \\
$1995-96$ & 8,771 & 612 & $6.98 \%$ & $8,699,055$ & 607,928 & $6.99 \%$ \\
$1996-97$ & 9,161 & 674 & $7.36 \%$ & $8,873,184$ & 630,121 & $7.10 \%$ \\
$1997-98$ & 8,660 & 640 & $7.39 \%$ & $8,856,662$ & 646,271 & $7.30 \%$ \\
$1998-99$ & 8,251 & 625 & $7.57 \%$ & $9,169,835$ & 685,842 & $7.48 \%$ \\
$1999-00$ & 8,251 & 634 & $7.68 \%$ & $9,257,539$ & 677,331 & $7.32 \%$ \\
$2002-03$ & 12,209 & 1,015 & $8.31 \%$ & $9,511,882$ & 734,457 & $7.72 \%$ \\
$2003-04$ & 9,214 & 703 & $7.63 \%$ & $10,447,569$ & 762,450 & $7.30 \%$ \\
\hline Source: Confidentialized Unit Record Files for the Survey of Income and Housing, various years.
\end{tabular}

Source: Confidentialized Unit Record Files for the Survey of Income and Housing, various years. 
Table 2

Means of Variables Full Sample and the Sub-Sample of Income Property Investors

\begin{tabular}{|c|c|c|c|c|c|}
\hline Acronym & Description & $\begin{array}{c}\text { Full } \\
\text { Sample }\end{array}$ & $\begin{array}{l}\text { Property } \\
\text { Investors }\end{array}$ & Difference & $\begin{array}{c}\text { Difference } \\
\text { T-Stat } \\
\end{array}$ \\
\hline RINCC & Rental Property Income & $7.0 \%$ & $100.0 \%$ & -- & -- \\
\hline NSW & New South Wales (Sydney) & $33.8 \%$ & $33.5 \%$ & $-0.3 \%$ & 0.8 \\
\hline VIC & Victoria (Melbourne) & $25.0 \%$ & $23.2 \%$ & $-1.8 \%$ & $2.9^{* *}$ \\
\hline QLD & Queensland (Brisbane) & $18.4 \%$ & $20.8 \%$ & $2.4 \%$ & $5.3^{* *}$ \\
\hline SA & South Australia (Adelaide) & $8.2 \%$ & $6.3 \%$ & $-2.0 \%$ & $7.8^{* *}$ \\
\hline WA & Western Australia (Perth) & $9.7 \%$ & $10.7 \%$ & $1.0 \%$ & $3.1^{* *}$ \\
\hline TAS & Tasmania (Hobart) & $2.5 \%$ & $2.0 \%$ & $-0.5 \%$ & $4.9^{* *}$ \\
\hline NTACT & Northern \& Capital Territories & $2.4 \%$ & $3.6 \%$ & $1.2 \%$ & $9.7^{* *}$ \\
\hline PERMINC & Permanent Income & $\$ 760$ & $\$ 1,020$ & $\$ 260$ & $56.0^{* *}$ \\
\hline TRANINC & Transitory Income & $-\$ 1$ & $\$ 195$ & $\$ 196$ & $37.0^{* *}$ \\
\hline FTEMP & Employed Full Time & $49.9 \%$ & $67.5 \%$ & $17.6 \%$ & $30.8^{* *}$ \\
\hline PTEMP & Employed Part Time & $7.7 \%$ & $6.0 \%$ & $-1.6 \%$ & $4.3^{* *}$ \\
\hline AGE & Age & 44.5 & 47.5 & 3.0 & $12.2^{* *}$ \\
\hline MALE & Male & $72.7 \%$ & $87.4 \%$ & $14.7 \%$ & $28.2^{* *}$ \\
\hline MARRIED & Married or DeFacto & $48.3 \%$ & $73.5 \%$ & $25.2 \%$ & $41.7^{* *}$ \\
\hline DIVORCED & Divorced, Separated, Widowed & $10.9 \%$ & $5.4 \%$ & $-5.5 \%$ & $15.4^{* *}$ \\
\hline CHILD1 & One Child & $10.7 \%$ & $13.3 \%$ & $2.7 \%$ & $6.0^{* *}$ \\
\hline CHILD2 & Two Children & $11.4 \%$ & $17.2 \%$ & $5.8 \%$ & $14.2^{* *}$ \\
\hline CHILD3 & Three or More Children & $5.8 \%$ & $8.2 \%$ & $2.4 \%$ & $8.7^{* *}$ \\
\hline OWNER & Home Owner & $56.2 \%$ & $79.5 \%$ & $23.3 \%$ & $37.8^{* *}$ \\
\hline FIRSTHO & First Homeowner & $4.2 \%$ & $2.6 \%$ & $-1.6 \%$ & $7.3^{* *}$ \\
\hline NMORT1 & One Mortgage & $22.4 \%$ & $27.7 \%$ & $5.3 \%$ & $9.8^{* *}$ \\
\hline NMORT2 & Two or More Mortgages & $3.2 \%$ & $5.8 \%$ & $2.6 \%$ & $11.7^{* *}$ \\
\hline NOBS & Number of Observations & 91,523 & 6,399 & & \\
\hline
\end{tabular}


Table 3

Panel Estimates of the Impact of Investment Determinants across the Real Estate Cycle

\begin{tabular}{|c|c|c|c|c|c|c|}
\hline \multirow[b]{2}{*}{ Parameter } & \multicolumn{3}{|c|}{ Model 1} & \multicolumn{3}{|c|}{ Model 2} \\
\hline & Estimate & t-Stat & $\begin{array}{r}\text { Diff. } \\
\text { Effect }\end{array}$ & Estimate & t-Stat & $\begin{array}{r}\text { Diff. } \\
\text { Effect }\end{array}$ \\
\hline Intercept & -5.013 & $(-64.170)^{* *}$ & -- & -5.279 & $(-61.469)^{* *}$ & -- \\
\hline Victoria (Melbourne) & -0.082 & $(-2.255)^{* *}$ & 0.001 & -0.080 & $(-2.214)^{* *}$ & 0.001 \\
\hline Queensland (Brisbane) & 0.237 & $(6.288)^{* *}$ & 0.006 & 0.244 & $(6.437)^{* *}$ & 0.006 \\
\hline South Australia (Adelaide) & -0.242 & $(-4.187)^{* *}$ & 0.007 & -0.244 & $(-4.217)^{* *}$ & 0.008 \\
\hline Western Australia (Perth) & 0.159 & $(3.359)^{* *}$ & 0.002 & 0.168 & $(3.522)^{* *}$ & 0.002 \\
\hline Tasmania (Hobart) & -0.154 & $(-1.599)^{* *}$ & 0.002 & -0.149 & $(-1.545)^{*}$ & 0.002 \\
\hline Northern \& Capital Territories & 0.346 & $(4.462)^{* *}$ & 0.009 & 0.334 & $(4.293)^{* *}$ & 0.009 \\
\hline Permanent Income $(\times 100)$ & 0.202 & $(32.640)^{* *}$ & 0.522 & 0.239 & $(32.369)^{* *}$ & 0.620 \\
\hline Transitory Income $(\times 100)$ & 0.053 & $(23.209)^{* *}$ & 0.109 & 0.052 & $(22.799)^{* *}$ & 0.108 \\
\hline Full Time & -0.172 & $(-3.573)^{* *}$ & -0.032 & -0.606 & $(-8.530)^{* *}$ & -0.111 \\
\hline Part Time & 0.222 & $(3.595)^{* *}$ & -0.003 & -0.012 & $(-0.171)$ & 0.000 \\
\hline Age & 0.007 & $(5.252)^{* *}$ & 0.017 & 0.003 & $(2.016)^{*}$ & 0.007 \\
\hline Male & -0.144 & $(-2.726)^{* *}$ & -0.022 & -0.215 & $(-4.031)^{* *}$ & -0.033 \\
\hline Married or DeFacto & 0.217 & $(4.679)^{* *}$ & 0.054 & 0.201 & $(4.272)^{* *}$ & 0.050 \\
\hline Divorced, Separated, Widowed & -0.177 & $(-2.726)^{* *}$ & 0.011 & -0.240 & $(-3.524)^{* *}$ & 0.015 \\
\hline 1 Child & -0.090 & $(-2.049)^{* *}$ & -0.002 & -0.102 & $(-2.317)^{* *}$ & -0.002 \\
\hline 2 Children & -0.031 & $(-0.735)$ & -0.002 & -0.049 & $(-1.160)$ & -0.003 \\
\hline 3+ Children & -0.134 & $(-2.485)^{* *}$ & -0.003 & -0.149 & $(-2.737)^{* *}$ & -0.004 \\
\hline Home Owner & 0.819 & $(19.344)^{* *}$ & 0.183 & 0.844 & $(19.668)^{* *}$ & 0.189 \\
\hline First Home Owner & -0.791 & $(-9.350)^{* *}$ & 0.014 & -0.808 & $(-9.521)^{* *}$ & 0.014 \\
\hline No. Mortgages $=1$ & -0.529 & $(-14.840)^{* *}$ & -0.026 & -0.524 & $(-14.540)^{* *}$ & -0.026 \\
\hline No. Mortgages $=2$ & -0.145 & $(-2.293)^{* *}$ & -0.003 & -0.009 & $(-0.138)$ & 0.000 \\
\hline 1994-95 Survey & & & & 0.465 & $(5.814)^{* *}$ & -0.002 \\
\hline 1995-96 Survey & & & & 0.607 & $(7.679)^{* *}$ & 0.000 \\
\hline 1996-97 Survey & & & & 0.605 & $(7.720)^{* *}$ & 0.003 \\
\hline 1997-98 Survey & & & & 0.570 & $(7.356))^{* *}$ & 0.003 \\
\hline 1998-99 Survey & & & & 0.469 & $(6.135)^{* *}$ & 0.004 \\
\hline 1999-00 Survey & & & & 0.521 & $(6.714)^{* *}$ & 0.005 \\
\hline 2002-03 Survey & & & & 0.475 & $(6.229)^{* *}$ & 0.005 \\
\hline 2003-04 Survey & & & & 0.107 & $(1.410)$ & 0.001 \\
\hline LLF & $-20,608$ & & & $-20,536$ & & \\
\hline
\end{tabular}


Table 4

Tests of Homogeneity of the

Parameter Estimates across Surveys

\begin{tabular}{lccc}
\hline Survey & Likelihood & & \\
Ratio & Restrictions & Prob. Value \\
\hline \hline $1990-91$ & 75.1 & 21 & 0.000 \\
$1994-95$ & 38.3 & 23 & 0.023 \\
$1995-96$ & 38.2 & 23 & 0.024 \\
$1996-97$ & 55.7 & 23 & 0.000 \\
$1997-98$ & 19.4 & 23 & 0.675 \\
$1999-00$ & 42.4 & 23 & 0.008 \\
$2000-01$ & 36.5 & 23 & 0.037 \\
$2002-03$ & 41.4 & 23 & 0.011 \\
$2003-04$ & 46.8 & 22 & 0.002 \\
\hline All surveys & 871.5 & 203 & 0.000 \\
\hline
\end{tabular}




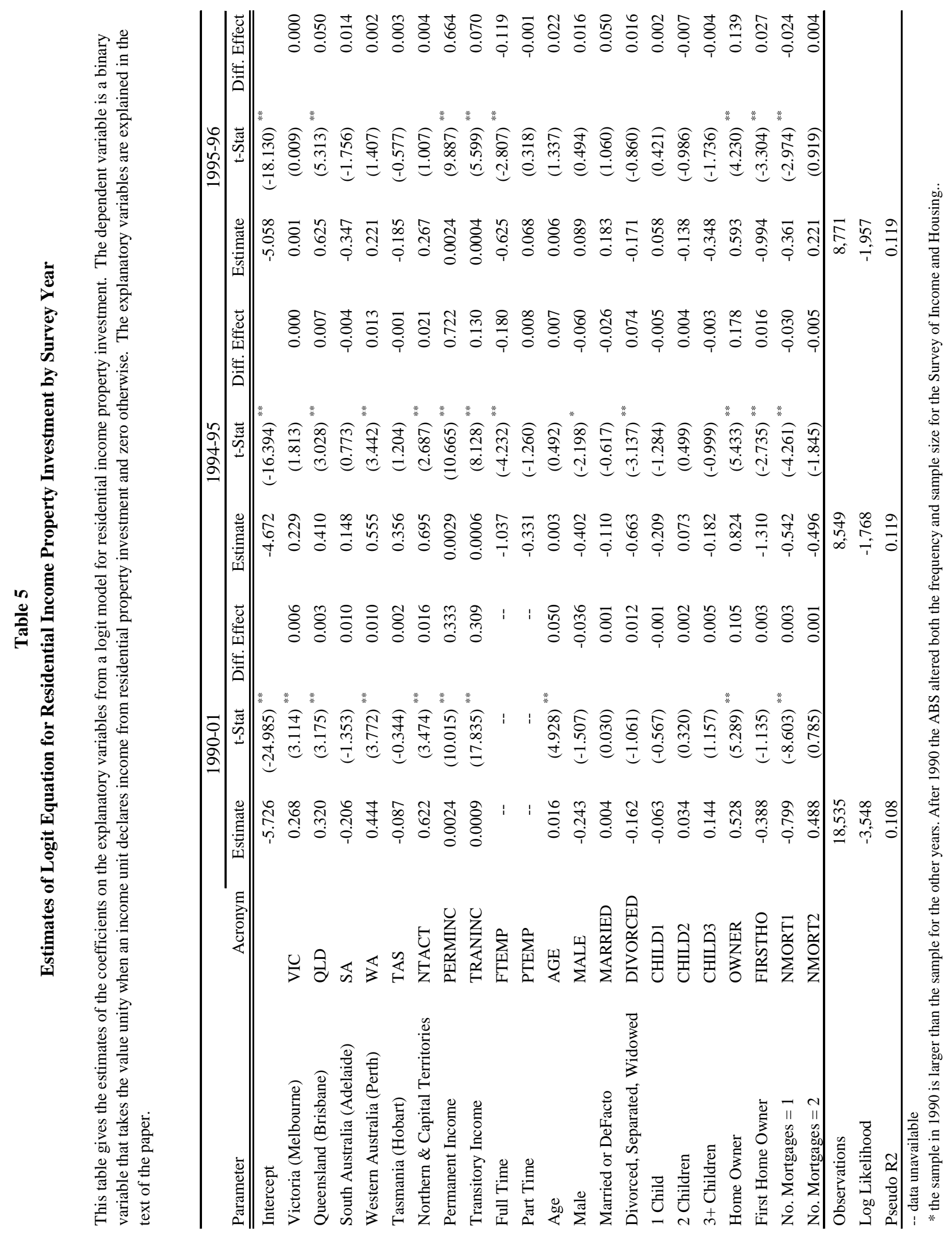




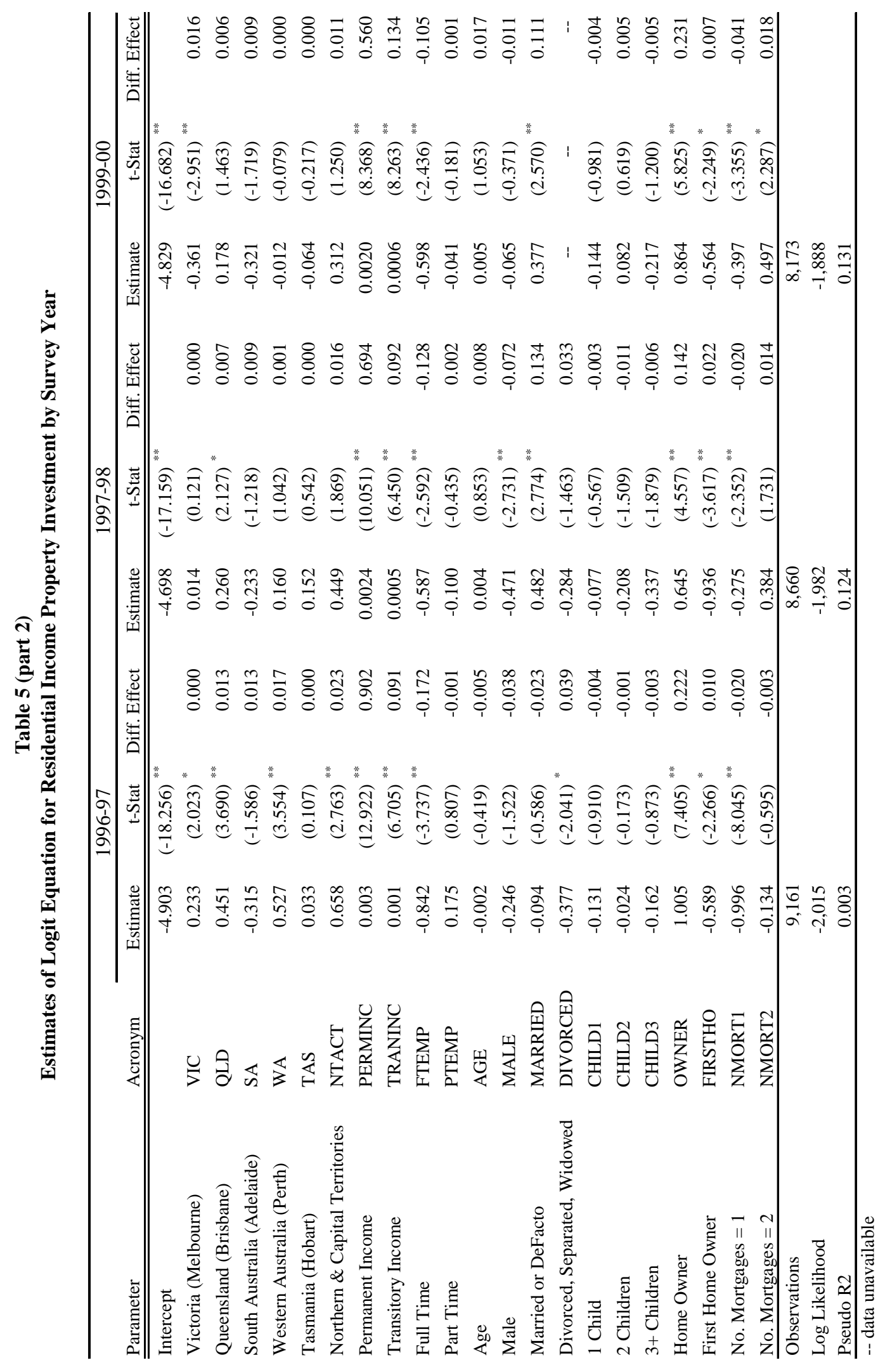




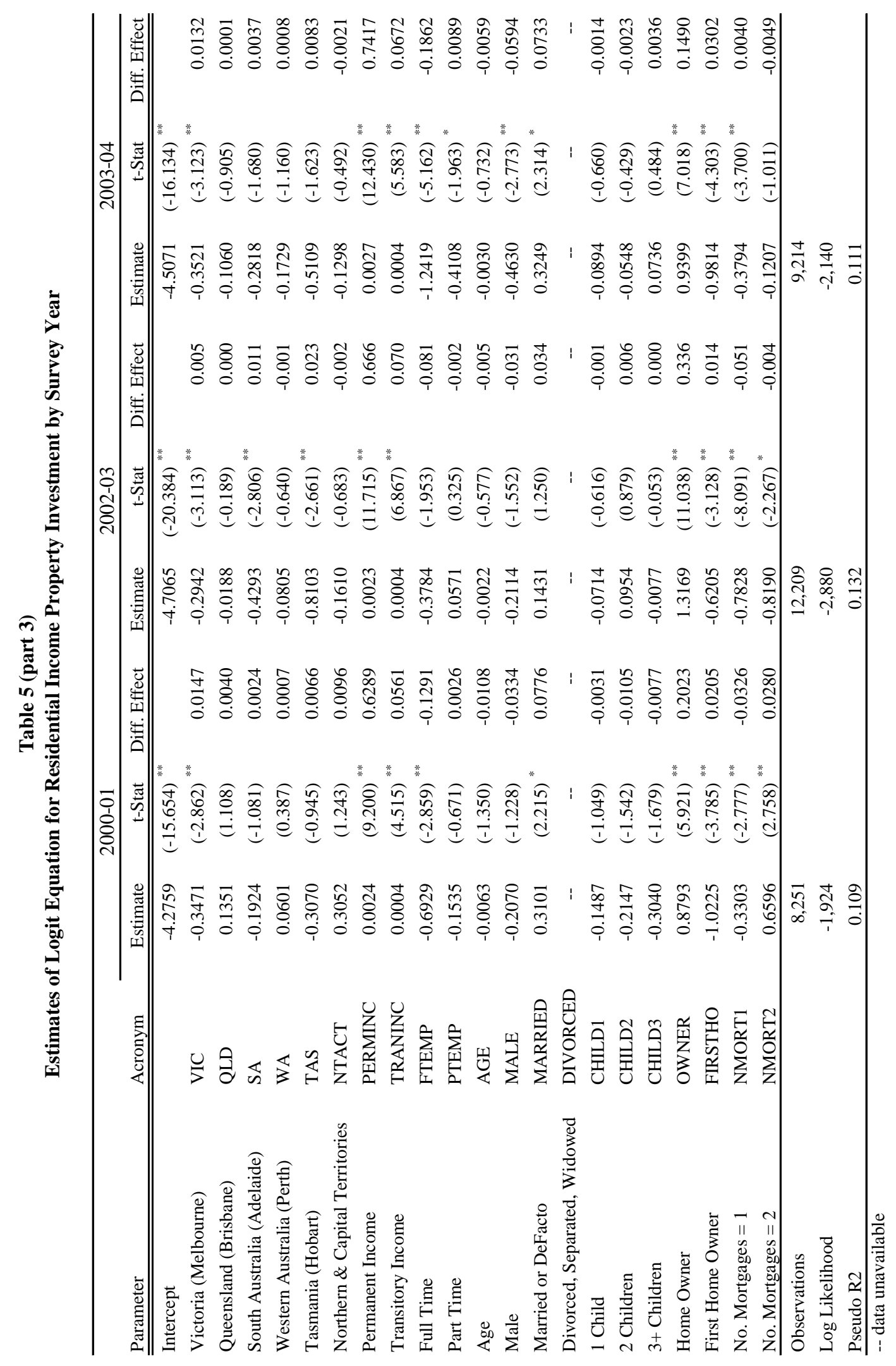


Figure 1

Percentage of Mortgage Commitments used for

Residential Income Property Investment and

Prices of Established Homes in Sydney

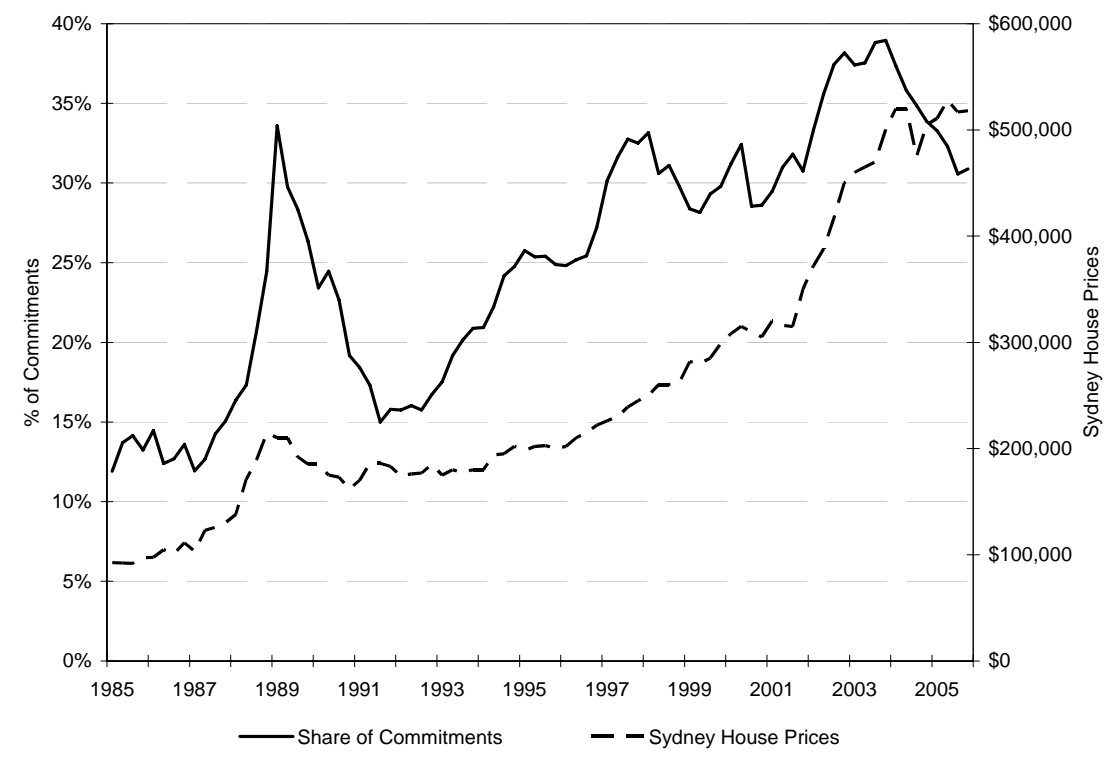

Source: Reserve Bank of Australia and Real Estate Institute of Australia (REIA) 
Figure 2

Percent of Income Units that are Income Property Investors and Annual Sydney Property Price Appreciation

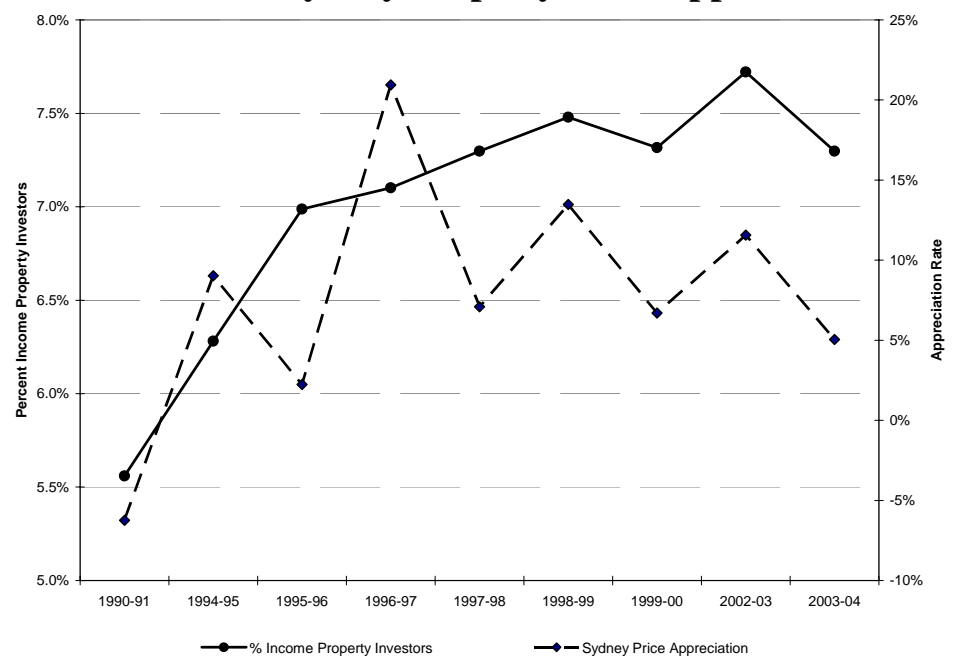

Source: Confidentialized Unit Record Files for Survey of Income and Housing, various years and Real Estate Institute of Australia 
Figure 3

Differences between the Percentage of Mortgaged Income Property Investors and the Percentage of Mortgaged Income Units in the General Population

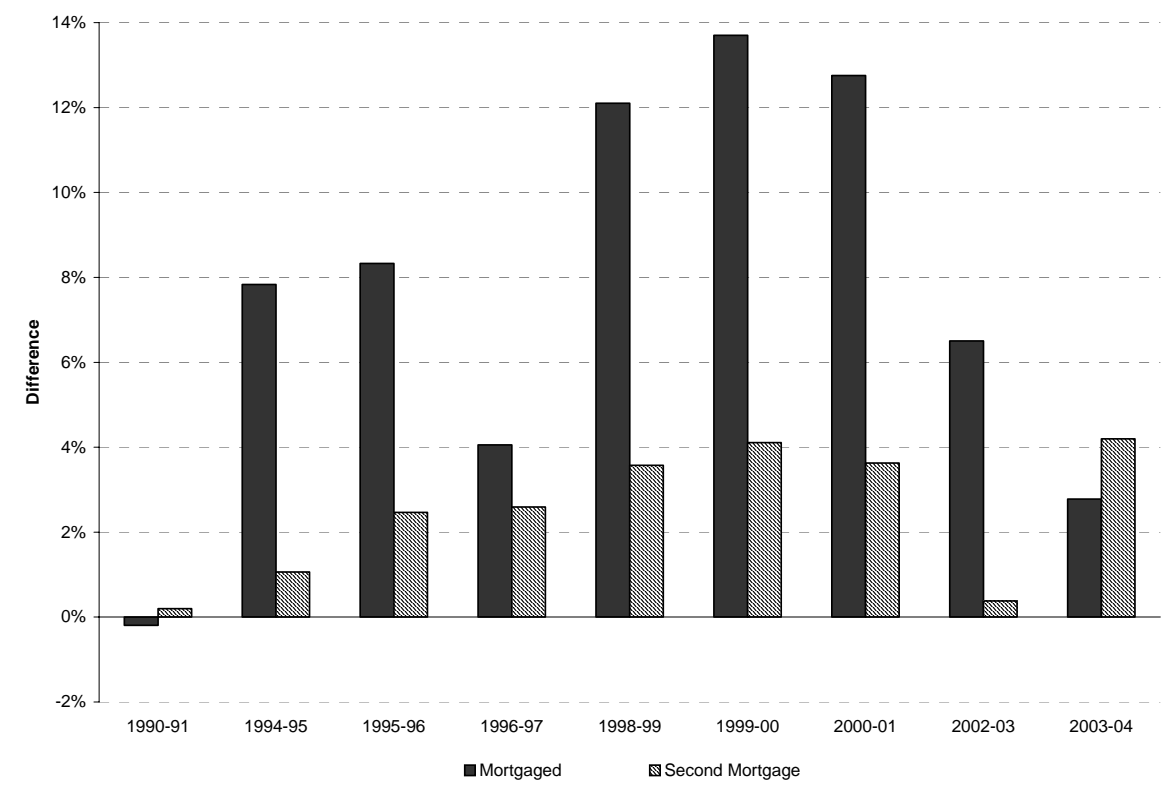


Figure 4

Changes in the Regional Incidence of Residential Income Property Investment across the Real Estate Cycle

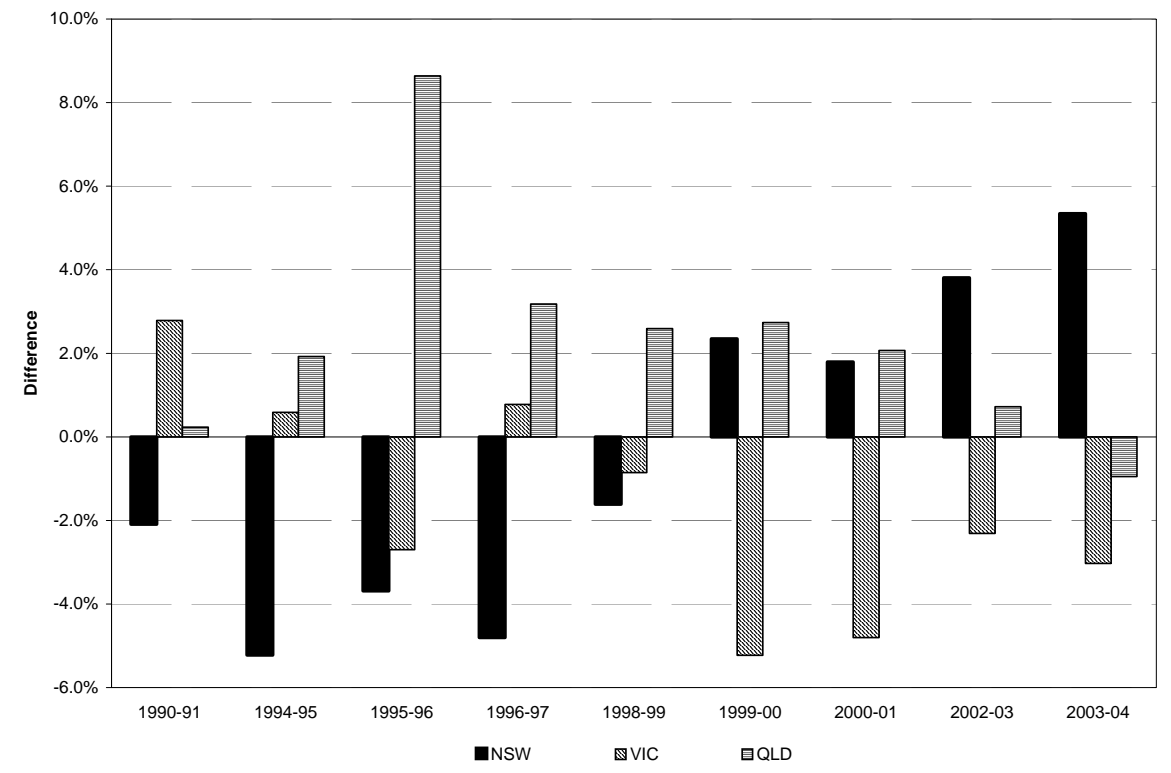


Figure 5

Effects of Investment Determinants by Survey Year
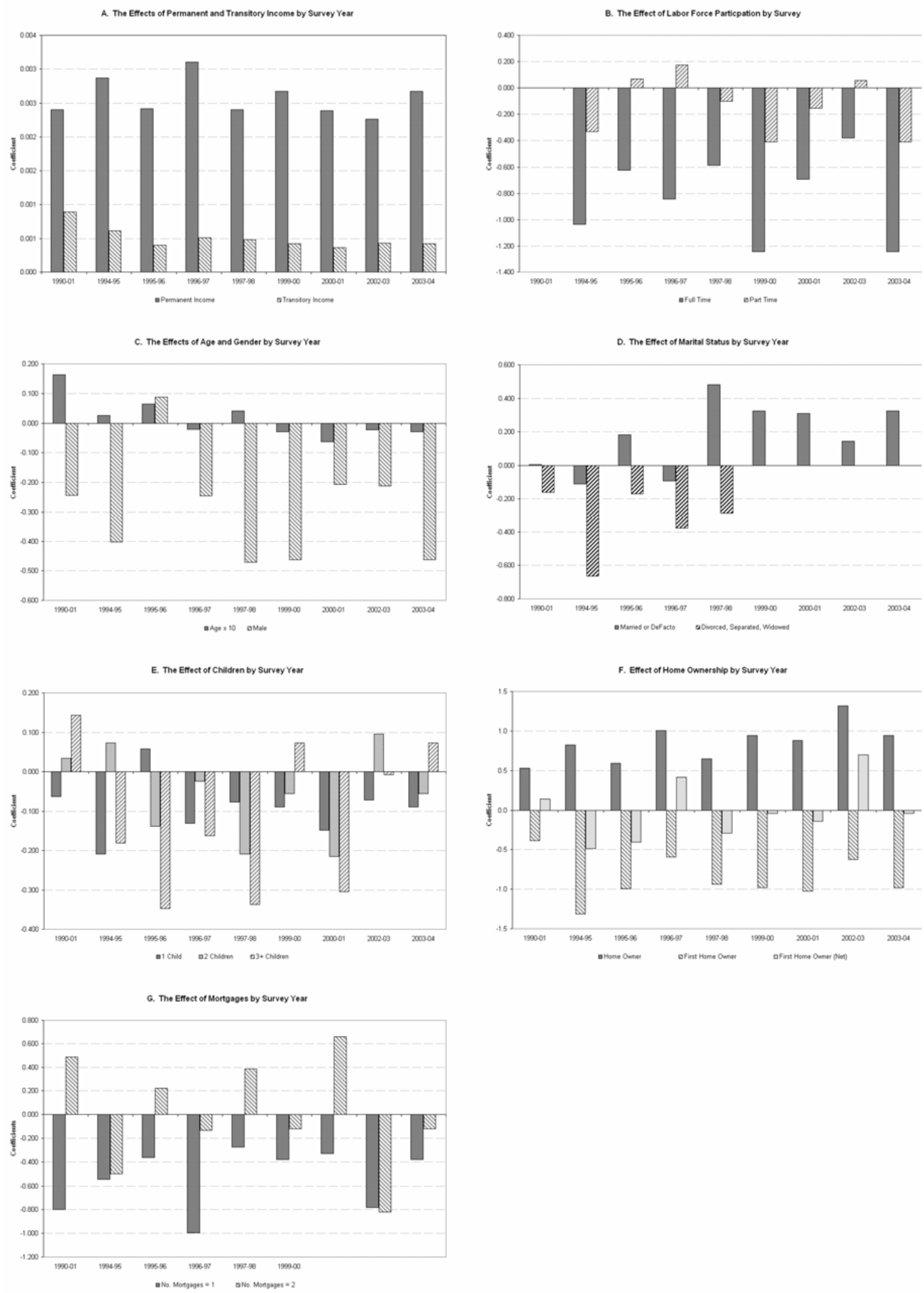


\section{Footnotes}

${ }^{1}$ DiPasquale (1999) provides an insightful review of the housing supply literature.

2 The remaining $40 \%$ is provided by government, non-profit institutions, employers and corporations.

${ }^{3}$ Benjamin, Torre and Musumeci (1998) examine the rationale for leasing versus owning in the commercial real estate sector.

${ }^{4}$ Ambrose and Linneman (2001) provide a discussion of the organizational structure and operating characteristics of REITs.

${ }^{5}$ Specifically, Meyer and Wieand show that $E\left(c_{k}\right)=R F \times P_{k}+\lambda \beta_{l k}$ where $c_{k}$ is the net cash flow to a land-

lord from dwelling unit $k, R F$ is the risk-free rate, $P_{k}$ is the maximum offer price for dwelling unit $k, \lambda$ is the (constant) marginal price of risk and $\beta_{k}$ is the beta of the net cash flows with the market portfolio (excluding housing). Rearranging gives the maximum offer price as $P_{k}=\left(E\left(c_{k}\right)-\lambda \beta_{l k}\right) / R F$, so that $P_{k}$ is decreasing in beta. Since increasing unsystematic risk is the root cause of lower betas, we have the result that $P_{k}$ is increasing in non-diversifiable risk.

${ }^{6}$ Their finding of a slight downward trend in the betas of equity real estate investment trusts (EREITs) corroborated previous studies.

${ }^{7}$ In Australian statistics, the prices of established homes refer to the prices of houses in the resale market for houses. Separate series are available for new houses.

${ }^{8}$ The suggestion that the high percentage of mortgage commitments is due to high house prices does not stand up to scrutiny. The value of all mortgage commitments will increase with house prices. Therefore, both the numerator and denominator of the percentage are affected positively by house prices.

${ }^{9}$ See Van Der Heijda and Boelhouwer (1996) for the details of private residential rental sector in European countries.

${ }^{10}$ For a discussion of these factors, see Kohler and Rossiter (2005).

11 The results of these regressions are available on request to the corresponding author.

12 The Survey of Income and Housing (SIH) was previously known as the Survey of Income and Housing Costs.

${ }^{13}$ A table containing a detail breakdown of the means, the difference of means and the $t$-statistics for each survey is available from the authors on request.

${ }^{14}$ In the next section, we show that having children reduces the likelihood of investing in rental property. The implication of our two findings is that other factors in the decision to invest outweigh the effect of having children.

15 The market in Perth (WA) is a notable exception. A boom in resource sector employment and income is fuelling a property price boom in Perth. 